\title{
Constipation and Aroma Massage in Elderly Individuals
}

\section{Yaşlı Bireylerde Konstipasyon ve Aroma Masajı}

\author{
(D) Diğdem LAFÇI
}

Mersin University Faculty of Nursing, Division of Nursing, Mersin, Turkey

\begin{abstract}
Constipation is a gastrointestinal motility disorder characterized by decreased bowel movements or difficulty in the defecation process. In the first step of non-pharmacological measures in constipation management, it is generally recommended to increase regular physical activity, and fluid and fiber consumption. In the medical treatment of chronic costipation; suppositories, laxatives and enemas are used. However, the long-term use of some laxatives can cause increased constipation and harmful side effects, including fecal impaction. Abdominal aroma massage is an inexpensive, noninvasive method that can be applied by nurses for the treatment of constipation. It can also be done by the patient himself/herself. Studies have shown that abdominal aroma massage stimulates peristalsis, shortens the colon transit time, increases the frequency of bowel movements, and reduces the accompanying feelings of pain and discomfort and the incidence of defecation in constipated patients. Abdominal effleurage, petrissage, kneading, vibration, and tapotement are thought to reduce muscle tension, increase local circulation, reduce indigestion, stimulate stomach acid secretion, increase appetite, stimulate peristalsis, alleviate constipation and reduce high blood pressure. In this article, the use and effects of abdominal aroma massage in constipation management will be explained.
\end{abstract}

Keywords: Abdominal aroma massage, constipation, elderly indivudals

\section{ÖZ}

Konstipasyon bağırsak hareketlerinde azalma veya defekasyon sürecinde güçlük ile karakterize gastrointestinal motilite bozukluğudur. Konstipasyon yönetimindeki nonfarmakolojik önlemlerin ilk basamağında genellikle düzenli fiziksel aktivite, sıvı ve lif tüketiminin arttırılması önerilmektedir. Kronik kostipasyonun medikal tedavisinde ise; supozituvarlar, laksatifler ve lavmanlar kullanılmaktadır. Fakat bazı laksatiflerin uzun süreli kullanımı, konstipasyonun artmasına ve fekal impakşını da kapsayan zararlı yan etkilere neden olabilir. Abdominal aroma masajı, konstipasyonun tedavisi için hemşireler tarafından uygulanabilecek, ucuz, zararlı etkisi olmayan, non-invaziv bir yöntemdir. Aynı zaman da hastanın kendisi tarafından yapılabilir. Araştırmalar abdominal aroma masajın konstipe hastalarda peristaltizmi uyardığını, kolon geçiş süresini kısalttığını, bağırsak hareketlerinin sıklığını arttırdığını ve eşlik eden ağrı ve rahatsızlık duygularını ve defekasyon görülme sıklığını azalttığını göstermiştir. Abdominal efloraj, petrisaj, yoğurma, vibrasyon ve tapotmanın kas gerginliğini azalttığı, yerel dolaşımı arttırdığı, hazımsızlığı azalttığı, midenin asit sekresyonunu uyardığı, iştahı arttırdığı, peristaltizmi uyardığı, konstipasyonu hafiflettiği ve yüksek kan basıncını düşürdüğü düşünülmektedir. Bu makalede konstipasyon yönetiminde abdominal aroma masajın kullanımı ve etkileri açıklanacaktır.

Anahtar Sözcükler: Abdominal aroma masajı, konstipasyon, yaşlı bireyler

Address for Correspondence: Diğdem LAFÇI, Mersin University Faculty of Nursing, Division of Nursing, Mersin, Turkey

E-mail: didemlafci@hotmail.com ORCID ID: orcid.org/0000-0001-7199-416X 


\section{Introduction}

The purpose of nursing is to help protect and improve the health of the individual in all stages of life. The purpose of the service provided to the elderly is to increase the quality of life of the individual and to ensure a healthy life (1). Nurses have active roles and responsibilities in the planning, delivery and development of services provided to the elderly $(2,3)$. Nurses should help elderly people to fulfill their daily life activities, to take care of themselves, to cope with their problems, to feel valuable, and to live in situations where they are not sufficient (1). Nurses have an important role in determining and meeting the health care needs of the elderly living in nursing homes. Changes in health status and systems with advancing age adversely affect the quality of life of the elderly and the elderly face many complex health problems (4).

Many diseases such as cardiovascular diseases, chronic lung diseases and diabetes are seen in the elderly due to factors such as sedentary lifestyle, unhealthy and unconscious dieting, and smoking. In addition, osteoporosis, visual disturbances, hearing difficulties, chronic pains and sleep disorders, mental disorders, urinary and fecal incontinence and constipation are common health problems in the elderly (5). It is stated that the prevalence of constipation increases with age and that $34 \%$ of women and $26 \%$ of men aged 84 or over have constipation problems. Constipation and defecation problems are more common among the elderly who stay in long-term care facilities and may cause morbidity $(6,7)$.

\section{Constipation and Its Epidemiology in Elderly People}

Constipation can be diagnosed with both objective and subjective measurable variables. Constipation is a functional bowel disease in which excessive strain during defecation, infrequent defecation and incomplete defecation are at the forefront. Although there are complaints of abdominal pain and/or abdominal distension, these symptoms should not be prominent symptoms and the symptoms in the patient should not meet the diagnostic criteria of irritable bowel symptoms. Symptoms should have started at least 6 months before diagnosis and should continue for the last 3 months (8).

Factors causing constipation can be listed as lifestyle factors, lack of regular bowel habits, malnutrition and insufficient fluid intake, feeding with foods poor in fiber, insufficient exercise, depression, and weakness of the pelvic floor muscles $(9,10)$. While constipation is a preventable and treatable problem, if left untreated, physical and psychological problems may develop. When constipation is not treated, it can cause health problems such as back pain, rectal pressure, anorexia, incontinence, confusion, nausea and vomiting, urinary dysfunction, fissure, rectal prolapse, hemorrhoids, intestinal obstruction, syncope and bowel perforation or stercoral peritonitis $(9,11,12)$.

Approximately $20 \%$ of healthy individuals in the community have one or more complaints related to constipation, including a decrease in stool frequency, hard stool, and excessive strain during defecation $(13,14)$. The prevalence of constipation increases with age, $34 \%$ of women and $26 \%$ of men aged 84 years or over experience constipation problems. Constipation is defined as an alarming, chronic and repetitive problem affecting $50-73 \%$ of the elderly, and it can cause serious problems in the elderly living in nursing homes $(6,14,15)$.

\section{Factors Causing Constipation and Treatment Methods}

Factors leading to digestive system problems in the elderly are tooth loss, decreased sensitivity in taste and smell receptors, decreased digestive system secretion and enzymes, decreased activity in bowel movements, decreased absorption in bowels, insufficiency of liver hemodynamics, decreased pancreatic response, sphincter insufficiency, and slowing of metabolism. At the same time, changes such as chronic diseases, polypharmacy, chronic inactivity, insufficient fluid intake, insufficient/ inadequate dieting, side effects of drugs and disruption of intestinal flora due to the use of antibiotics cause serious digestive system problems in the elderly $(9,14,16,17)$. These problems include eating difficulties, anorexia, indigestion, change in eating habits, absorption disorders and constipation $(18,19)$.

Inadequate bowel management may cause a decrease in the comfort and quality of life of the elderly (20). Early evaluation and diagnosis of constipation in the elderly, creating an appropriate bowel management plan and planning individual nursing interventions for bowel elimination are among the primary responsibilities of nurses $(15,21)$. Therefore, the nurse should determine the habits of the individual and include this information in the individualized care plan. It is important to collect data about the general practices regarding the discharge of the individual, to determine whether he or she is independent in performing the evacuation activity, and to reveal the coping mechanisms previously used for evacuation problems and chronic diseases (9).

There are many pharmacological and non-pharmacological approaches to prevent constipation. Generally, in the treatment of constipation, drugs (laxatives, enemas, suppositories, etc.) are used when non-pharmacological approaches such as changes in nutritional habits, adequate fluid intake, education, activities to develop healthy bowel habits, exercise, massage, aroma massage, biofeedback, stress management are not sufficient $(9,10,22,23)$.

Initiatives such as progressive relaxation, therapeutic touch, music therapy, and aromatherapy, which are called complementarysupportive therapeutic approaches, are used by nurses to help individuals meet their physical, emotional and psychological needs (24). In our country, aromatherapy and aromatherapy massage are frequently used as a nursing initiative. However, there is a study examining the effect of aromatherapy on constipation. Aromatherapy massage is an intervention that should be included in practices as a therapeutic nursing intervention in order to reduce the symptoms of constipation, increase the quality of life, and provide comfort $(25,26)$.

\section{Nursing Initiatives for Constipation}

Nurses should pay attention to health behaviors in order to gain useful habits that are always applicable and improve health (27). 
Individuals should be taught effective bowel habits at home, in hospitals, and in institutions that provide long-term care (28). Normally, nursing interventions including factors such as diet, exercise, squatting position, abdominal massage/aroma massage, timing and confidentiality should be planned and implemented for the development and maintenance of bowel habits $(29,30)$.

\section{a) Diet}

The nurse must first reveal the final nutritional status of the individual. The positive habits of the elderly person should be supported and education should be given to gain positive habits. Nutritional factors that facilitate intestinal evacuation are consuming warm/hot drinks and fibrous foods, and sufficient fluid intake. Drinking warm/hot drinks and fruit juices soften stool and increase peristalsis (27-30). Increasing the intake of fibrous and fiber foods reduces the risks of colon cancer, digestive system diseases and other cancer as well as providing regular bowel emptying. In addition, if there is no need for fluid restriction, the nurse should support the elderly person in taking 2000-3000 ml of fluid daily (29,30). Because it dilutes the liquid content and facilitates its passage through the column. When the amount of fluid in the body decreases, as peristalsis slows, more fluid is absorbed from the feces moving through the intestine causing the feces to harden. As a result, insufficient fluid intake causes constipation (27-30). Therefore, it is very important to regulate the nutrition of elderly people with constipation.

\section{b) Exercise}

Regular exercise programs such as walking, swimming, and cycling 3-5 times a week are important for maintaining normal gastrointestinal motility. Individuals who remain immobile due to illness should be mobilized as soon as possible, and active ROM (range of motion) exercises should be performed for bedridden individuals (27-30). The nurse should evaluate the elderly person's exercise situation and possibilities. Slow walking, which is reported to be the most appropriate exercise for the elderly person, should be encouraged.

\section{c) Timing and Confidentiality}

The nurse should inform the individual in which situations and when the feeling of defecation may occur $(29,30)$. Suppression of the feeling of defecation and the thought that defecation may take time are among the most important causes of constipation $(27,30)$. In order to evaluate the regularity of bowel movements, the individual should know his or her own normal defecation habits and fulfill these habits on time (30). If the individual is bedridden or gets help during movement, the nurse should give the individual a bedpan or help him/her go to the bathroom (28). Giving the person a bedpan in front of other people creates a feeling of embarrassment. In this case, the nurse should take measures to protect privacy and try to comfort the individual by talking about not interrupting defecation $(27,29,30)$.

\section{d) Squatting Position}

Squatting is a normal and proper position during defecation. Normal toilets provide this ease of posture and increase the intra-abdominal pressure of the individual and tighten the thigh muscles. However, since squatting is a very difficult situation for the elderly with diseases such as chronic arthritis, which causes weakness in joints and muscles, nurses should help the elderly to crouch and stand up (28). The elderly who are not likely to squat and have to use the toilet should be informed that they can create a squat effect by leaning forward while sitting on the toilet. Defecation is very difficult in immobile individuals. Since it is not possible for the muscles to contract in the supine position for defecation, the patient should be given a sitting position as much as possible when the badpan is given $(27,29,30)$.

\section{e) Abdominal Massage and Aroma Massage}

Massage is the art of touching to relax the whole or a certain part of the body. Massage is applied to reduce muscle tension, provide relaxation and stimulate blood circulation in tissues $(10,31,32)$.

Abdominal massage is a non-invasive massage method that is applied to the large intestine in a clockwise direction, including petrissage, effleurage, kneading and vibration movements in order to relax the abdominal wall. Abdominal massage is applied to the individual for 15 minutes $(33,34)$. Massage, applied by applying pressure to the front and back walls of the abdomen and treating the trigger points, stimulates the passage of gas and intestinal sounds, creates peristaltic stimulation, pushing the feces from the intestines to the rectum and reducing the symptoms of constipation (35). In addition, adominal massage stimulates local circulation, reduces muscle tension, stimulates gastric acid secretion and facilitates digestion (35).

Aroma massage is an integrative treatment method that combines the beneficial effects of massage and aromatherapy, making the care offered more effective (36). Aroma massage with diluted essential oils is a combined method that increases the effect of essential oils used in massage. It is known that aroma massage, which is the art of touching and which is applied to relieve the whole or a certain part of the body, has many effects on systems $(31,36,37)$. Absorption of essential oils and their incorporation into the bloodstream is accomplished by massage that provides dilatation of the blood vessels in the dermis (31).

It is known that applying aromatic oil (2-3 drops of selected essential oil containing oil) or lotion locally to the abdomen has an effect on bowel evacuation. In studies, fats have been found to increase bowel movements, the frequency of defecation, the amount of stool, to decrease colon spasm during colonoscopy, the symptoms of irritable bowel syndrome, the severity of constipation, strain during defecation, and to provide a feeling of complete discharge after defecation (38-46).

\section{Process Steps}

- The individual is primarily given the supine position. The head of the bed is raised $30-45^{\circ}$ if there are risky situations for the person given the supine position. If there is no unfavorable situation, a thin pillow is placed under the knees by bending the knees slightly in order to relax the abdomen. 
- The clothes between the lower edge of the ribs and the spina iliaca anterior superiors are removed. There should be no tight clothes that will prevent circulation in the pelvis. The remaining body parts are covered using two sheets.

- The person applying the massage stands on the right side of the patient, facing the patient.

- Before starting the massage, the abdomen is evaluated in terms of distension, flatulence, pain and intestinal fecal material.

- The process should not be applied immediately after meals. It should be ensured that the individual's urinary bladder is empty before the procedure. It can help take advantage of the gastrocolic reflex, especially in the morning or when the intestines are most active 30 minutes after meals.

- Manipulations are started in the left lower quadrant of the sigmoid colon.

- The three basic massage maneuvers for constipation, which are effleurage (3 times), petrissage (3 times), and vibration (3 times), are applied three times each during abdominal massage.

- Abdominal massage is started with effleurage, and the abdominal wall is relaxed. If abdominal massage is applied to the individual for the first time, the deep tissues cannot be reached during the massage due to the contraction of the individual's muscles when first touched. After this tension is removed with effleurage, the main maneuvers are started.

- In superficial effleurage, it is applied in the opposite direction of the heart, over the entire surface of the abdominal wall, over the iliac crest and on both sides of the pelvis, down to the groin.

- Deep effleurage is applied in the direction of column, horizontal column and descending column. The applied pressure increases the contractions in the large intestine. In the application of effleurage, the fingertips are placed on the symphsis pubis, moved on along the M.rectus abdominis with deep effleurage, the hands are opened sideways at the level of the lower ribs, moved on along the line of the transverse abdominal muscles and down to the middle area, and after reaching the starting point obliquely in the second effleurage turn. Effleurage is started on the cecum with the right hand at the bottom and the left hand at the top. It is moved upward on the ascending colon, the direction of the lower hand is changed while moving on the midline, proceeded downward on the descending colon, descended obliquely towards the pubis and passed over the bladder with superficial effleurage.

- Petrissage maneuver is applied with palms and fingers upward in the ascending colon and downward in the descending colon. During the application, the pressure is successively increased and decreased.

- In abdominal massage, friction movement is started in the distal of the descending colon and a $5 \mathrm{~cm}$ downward friction is applied each time and it is moved on to the starting point. Deep effleurage is used in between.

- In vibration, the hand does not move in any direction, the movement is limited to the muscle the hand is on. Vibration creates reflex physiological effects during its application for a long time and with sufficient intensity. The effect stimulates the nervous system and allows the muscles to relax. It reduces spasm in the intestine. At the same time, it enables the gas accumulated in the intestines to be removed from the body (34-36,47-51).

\section{Studies on Aroma Massage and Constipation}

Considering the studies examining the effects of aroma massage on constipation and intestinal problems in different age groups and diseases, it is seen that the oils used are castor, lavender, lemon, sweet fennel, grapefruit, black pepper, mint, rosemary and these oils are applied by nurses. In the studies conducted, the groups where aroma massage is applied are patients with cancer, patients with Guillian Barre disease, mentally disabled children, female students/women, women, patients undergoing colonoscopy and the elderly. The application times of the aroma massage vary between 5 and 20 days.

Although there are studies on the effect of aromatherapy massage on constipation in developed countries, one study on this issue has been found in our country (44). Studies have shown that aroma massage is applied in different populations, using different oils and at different application durations $(39,40,42-45)$. There are few studies examining the effect of abdominal massage applied with aromatic oils on constipation seen in the elderly $(43,44)$.

When looking at the studies examining the effect of aromatherapy on constipation and intestinal problems;

Kyle stated that castor oil compress applied to the abdominal area of elderly women with constipation increased bowel movements (41).

In a patient with Guillian Barre syndrome with constipation, as a result of the aromatherapy application consisting of a mixture of geranium flower, lavender, roman chamomile, lemon, sweet fennel, grapefruit, black pepper and mint, it was observed that stimulating abdominal massage resulted in defecation. It was reported that the patient requested this treatment as constipation developed (42).

In the study conducted by Kim et al. to determine the effect of aromatherapy on constipation seen in the elderly, it was concluded that the average score of the constipation rating scale after 10 days of aromatherapy massage decreased significantly and that the bowel movements were faster than the control group (43).

In the study by Jeon and Jung, abdominal massage was applied to 31 dependent patients with cerebrovascular events accompanied by aromatherapy. While there was a significant increase in the frequency of defecation in the treatment group, it was observed that there was a significant improvement in constipation according to the constipation scales (46).

In the study conducted by Chung and Choi, it was found that the frequency of defecation increased and the severity of constipation decreased after aromatherapy massage in college students (39).

In the study conducted by Lai et al., it was observed that aroma massage reduced the severity of constipation in cancer patients (45). 
In the study conducted by Nam et al., it was observed in hospitalized children that the amount of stool in the group who received aroma massage 5 times a week increased compared to the group that received aroma massage 3 times a week (40). In addition, peppermint oil was shown to reduce colon spasm and symptoms of irritable bowel syndrome during colonoscopy and to have a beneficial digestive antispasmia (38).

In our country, in the study conducted by Gürol, Arslan, and Eşer, it was concluded that the castor oil package was not effective on the number of bowel movements and the amount of stool in the elderly. It was reported that the stool consistency score increased, straining during defecation decreased, and that it provided the feeling of complete discharge after defecation (44).

\section{Conclusion}

Since the studies conducted mostly on abdominal massage, different age groups and diseases, there was a need for more studies on evidence-based practices that would examine the effect of aroma massage on relieving constipation. Abdominal aroma massage should be applied as an integrated treatment method in addition to laxatives in order to reduce constipation and alleviate constipation complaints. Nurses working in nursing homes or clinics that provide care to the elderly should be trained on the application of aroma massage within the scope of the certificate program and patients and their relatives should be provided with one-to-one practice. It is thought that informing nurses working with elderly people to increase their awareness about constipation is also very important.

Peer-review: Internally and externally peer reviewed.

Financial Disclosure: The authors declared that this study received no financial support.

\section{References}

1. Lee WT, Ko S, Lee KJ. Health promotion behaviors and quality of life among community-dwelling elderly in korea: a cross-sectional survey. International Journal of Nursing Studies 2006;293-300.

2. Sakano LM, Yoshitome AY. Diagnosis and nursing interventions on elderly inpatients. Acta Paulista Enfermagem 2007;495-498.

3. Marin MJS, Rodrigues LCR, Druzian S, Cecilio LCO. Nursing diagnoses of elderly patients using multiple drugs. Revista Escolade Enfermagem 2010;46-51.

4. Hakverdioğlu G, Türk G, Khorshid L, Eşer İ. Huzurevinde kalan yaşlılarda konstipasyon tanısının değerlendirilmesi. İstanbul Üniversitesi Florance Nightingale Hemşirelik Dergisi 2011;83-88.

5. Tiftik S,Kayış A,İnanır İ. Yaşlı bireylerde sistemsel değişiklikler, hastalıklar ve hemşirenin rolü. Akad Geriatri 2012;4:1-11.

6. Orozco J, Orenstein A, Sterler S, Stoa J. Chronic constipation in the elderly. Theamerican Journal Of Gastroenterology 2012;107:18-25.

7. Gallagher PF, Mahony DO, Quigley EMM. Management of chronic constipation in elderly. Drugs and Aging 2008;807-821.

8. Kaya M, Kaçmaz H. Roma IV kriterlerine göre fonksiyonel bağırsak hastalıklarının yeniden değerlendirilmesi. Güncel Gastroentroloji 2016;20(4):393-407.
9. Martha V, Manning RN. Assessment of digestive and gastrointestinal function, management of patients with intestinal and rectal disorders. In: Suzanne C, O’Connell Smeltzer RN, FAAN Brenda G, Bare RN, editors Brunner \& Suddarth's Textbook of Medical Surgical Nursing. Philadelphia: Lippincott Williams and Wilkins; 2006.p.1029.

10. Akça Ay F. Sindirim Sistemi ve Uygulamaları. İçinde: Akça Ay F, editör. Temel Hemşirelik Kavramlar İlkeler ve Uygulamalar. İstanbul: Nobel Tip Kitabevleri; 2008.p.20-493.

11. Toprak İ, Soydal T, Bal E, İnan F, Aksakal N. Yaşlı Sağlığı, Ankara: T.C. Sağlık Bakanlığı Temel Sağlık Hizmetleri Genel Müdürlüğü Pelin Ofset; 2002.p.67-71.

12. Kaya H. Bağırsak Boşaltımı. İçinde: Atabek Aştı T, Karadağ, A, editörler. Hemşirelik Esasları Hemşirelik Bilimi ve Sanat. İstanbul: Akademi Basın ve Yayıncılık; 2012.p.941-961.

13. Talley NJ, Jones M, Nuyts G, Dubois D. Risk factors for chronic constipation based on a general practice sample. The American Journal of Gastroenterology 2003;1108-1111.

14. Yönem Ö, Arslan S. Yaşlıda Diare ve Konstipasyon. İçinde: Arıŏul S, editör. Geriatri ve Gerontoloji. Ankara: Medikal ve Nobel Yayınevi; 2006.p.501-512.

15. Frank L, Flynn J, Rothman M. Use of a self-report constipation questionnaire with older adults in long-term care. The Gerontologist 2001;778-786.

16. Holt PR. Gastrointestinal diseases in the elderly. Current Opinion in Clinical Nutrition and Metabolic Care 2003;41-48.

17. Kaçmaz Z, Kaşıkçı M. Effectiveness of bran suplement in older orthopaedic patients with constipation. Journal of Clinical Nursing 2005;928-936.

18. Esen A. Yaşlılık ve Beslenme. İçinde: Fadıloğlu Ç, editör. İleri Geriatri Hemşireliği. İzmir: Meta Basım Matbaacılık; 2006.p.63-76.

19. Taylor CR, Lemone P, Lillis C, Lynn P. Aromatherapy, Complementary and Alternative Therapies, Effects of Applying Heat. Wolters Kluwer/ Lippincott Williams and Wilkins; 2008.p.758-759.

20. Hsieh C. Treatment of constipation in older adults. American Family Physician 2005;2277-2284.

21. Richmond JP, Wright ME. Development of a constipation risk assessment scale. Clinical Effectiveness in Nursing 2005;37-48.

22. Beloosesky Y, Grinblat J, Weiss A. Electrolyte disorders following oral sodium phosphate administration for bowel cleansing in elderly patients. Arch International Medicine 2003;803-810.

23. Dennison C, Prasad M, Lloyd A. The health-related quality of life and economic burden of constipation. Pharmacoeconomics 2005;461-476.

24. Kuzeyli Yıldırım Y, Fadıloglu Ç, Uyar M. Palyatif kanser bakımında tamamlayıcı tedaviler. Ağrı Dergisi 2006;26-32.

25. Karagöz G. Sırt, boyun, bel ağrıları olan ve ameliyat programına alınan nöroşirürji hastalarının ağrı gidermede kullandıkları tamamlayıcı ve alternatif tedaviler. İstanbul: İstanbul Üniversitesi. 2006.

26. Wyatt G, Sikorskii A, Wills CE, Su H. Complementary and alternative medicine use, spending, and quality of life in early stage breast cancer. Nursing Research 2010;58-66. 
27. Birol L. Hemşirelik Süreci. İzmir: Etki Matbaacılık Yayıncılık; 2013.p.86-321.

28. Potter AP, Perry AG. Fundamentals of Nursing. St Louis: Mosby; 2005.p.910-928.

29. Harkreader H, Hogan MA, Thababen M. Fundamentals of Nursing: Caring and Clinical Judgment. Philedelphia: Sounders; 2007.p.717748.

30. Berman A, Snyder SJ, Kozier B, Erb G. Aromatherapy, Complementary and Alternative Healing Modalities, Kozier and Erb's Fundamentals of Nursing, Concepts, Process and Practice, New Jersey: Upper Saddle River; 2008.p.334-335.

31. McNeilly P. Complementary therapies for children: aromatherapy. Paediatric Nursing 2004;28-30.

32. Süzen B, Akça Ay F, Demir Y. Deri ve öz bakım uygulamaları. uyku ve uyku ile ilgili uygulamalar. İçinde: Akça Ay F, editör. Temel Hemşirelik Kavramlar, İlkeler, Uygulamalar. İstanbul: Nobel Tip Kitabevleri; 2010.p.314-694.

33. Preece J. Introducing abdominal massage in palliative care for the relief of constipation. Complementary Therapies in Nursing \& Mdwifery 2002;8:101-105.

34. Emly MC. Abdominal massage for constipation. In: Halsam J. and Laycock J, Editors. Therapeutic Management of Intcontinance and Pelvic Pain. London: 2007.p.223-225.

35. Sinclair M. The use of abdominal massage to treat chronic constipation. Journal of Bodywork and Movement Therapies $2011 ; 436-445$.

36. Hunt V, Randle J, Freshwater D. Paediatric nurses' attitudes to massage and aromatherapy massage. Complementary Therapies in Nursing and Midwifery 2004;194-201.

37. Buckle J. Clinical Aromatherapy. China: Churchill Livingstone; 2003.p.45-58.

38. Maddocks-Jennings W, Wilkonson JM. Aromatherapy practice in nursing: literature review. Journal of Advanced Nursing 2004;93103.

39. Chung M, Choi E. A comparison between effects of aroma massage and meridian massage on constipation and stress in women college students. Journal Korean Acad Nursing 2011;41(1):26-35.
40. Nam MJ, Bang Y, Kim TI. Effects of abdominal meridian massage with aroma oils on relief of constipation among hospitalized children with brain related disabilities. Korean Society of Nursing Science 2013; 43(2):47-255.

41. Kyle L. Aromatherapy for elder care. The International Journal of Aromatherapy 1999;170-177.

42. Shirreffs MC. Aromatherapy massage for joint pain and constipation in patient with guillian barre. Complementary Therapies in Nursing and Midwifery 2001;78-83.

43. Kim MA, Sakong JK, Kim EJ, Kim EH. Effect of aromaterapy massage fort he relief of constipation in the elderly. Journal Korean Acad Nursing 2005;35(1):56-64.

44. Gürol-Arslan G, Eşer İ. An examination of the effect of castor oil packs on constipation in the elderly. Complementary Therapies in Clinical Practice 2011;58-62.

45. Lai TKT, Cheung MC, Lo CK, Ng KL, Fung YH, Tong M, Yau CC. Effectiveness of aroma massage on advanced cancer patients with constipation: A pilot study. Complementary Therapies in Clinical Practice 2011;37-43.

46. Jeon SY, Jung HM. The effects of abdominal meridian massage on constipation among CVA patients. Taehan Kanho Hakhoe Chi 2005;35(1):135-42.

47. Fritz S. Mosby's fundamentals of the therapeutic massage. 4th ed. China:Mosby Elsevier Company, 2009.p.332-333.

48. Tuna N. A'dan Z'ye masaj. İstanbul: Nobel Tip Kitapevi, 2011.p.1739.

49. Turan N, Aşıı T. Konstipasyon yönetiminde abdominal masajın önemi. Anadolu Hemşirelik ve Sağlık Bilimleri Dergisi 2015;18: 2.

50. Woodward S. Assessment and management of constipation in older people. Nurs Older People 2012;24(5):21-6.

51. Yüksel İ, Baltacıoğlu S. Klasik masaj teknikleri. İçinde: Yüksel İ, Editör. Masaj Teknikleri. Ankara: Öz Baran Ofset, 2010.p.82-155. 